\section{Marquette raves on}

The Marquette University Raynor Library was the scene of a student organized "flash rave" during the fall semester finals week in December 2009. Approximately 700 students converged on the library cheering, dancing, crowd-surfing and, chanting "We Are Marquette!" Marquette students organized the flash rave after seeing online video of a similar event at the University of North Carolina at Chapel Hill. Library staff members were alerted to the flash rave through Facebook and were prepared to support the students. The library even provided an extension cord for the music. "It was a lot of energy, and what a great way to end the semester," noted Dean of Libraries Janice Welburn.

The ten-minute flash rave became an Internet meme after students posted a video of the event on YouTube, prompting coverage by news outlets such as MSNBC and CNN. Video of the Marquette flash rave is available at www. youtube.com/watch? $=$ =HMqs $5 \mathrm{j} 8 \mathrm{nNcw}$.

\section{Harford Community College essay contest}

In conjunction with its 10th anniversary, the Harford Community College (HCC) Library recently held a student essay contest on "The Library: Past, Present, Future." The three winners announced were Natalie Shaw, Sheila Hooker, and Helga Hoffman. Shaw, a history major, was named the firstprize winner and received a gift certificate for an iPod Touch. Hooker, a paralegal studies major, received a gift certificate to purchase text books at the HCC College Store for second place, and Hoffman, a general studies major, received a reserved parking spot for one month for her third place

prize. The first place essay, "Bookaholics Anonymous: A Childhood Spent Among the Stacks," will be published in The Harford Owl, HCC's student newspaper.

"Harford County libraries and librarians of all types (school, public, and college) received high praise in the essays," said Library Director Carol Allen. "Many students wrote of how a librarian they encountered early in life made

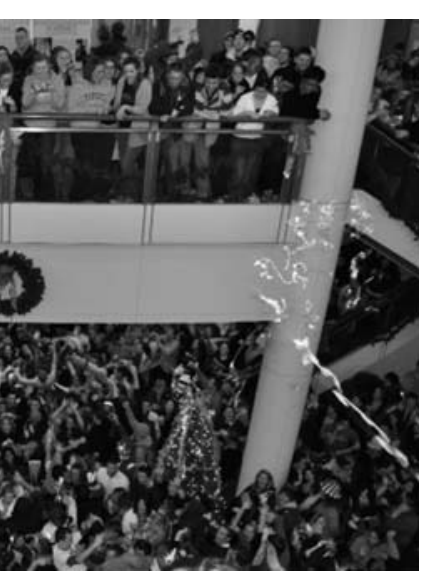
a big difference in their lives. This is what libraries are all about-changing lives and making a difference."

The contest was open to all currently enrolled HCC students. A short piece of writing (800-1,200 words) expressing the student's view on "The Library: Past, Present, Future" was judged based on organization, writing style, clarity, relevance to topic, grammar, and punctuation. All three winning essays were printed on posters and placed on display in the library during January 2010.

\section{Gale releases iPhone app}

Gale recently announced the launch of the AccessMyLibrary (AML) mobile application for the iPhone. The new application allows iPhone users to access local library resources and conduct research from their mobile device. The application is available as a free download, with content paid for by the library being accessed. AML can be downloaded from the iTunes store and can also be accessed through the Web at www. accessmylibrary.com.

\section{Free at Last? Slavery in Pittsburgh in the 18th and 19th Centuries}

Free at Last? Slavery in Pittsburgh in the 18th and 19th Centuries, a recent display at the University of Pittsburg's (UP) Senator John 


\section{ACRL selects value of academic libraries researcher}

ACRL has selected of Megan Oakleaf, assistant professor in the iSchool at Syracuse University, as lead researcher for its value of academic libraries project. A recognized expert in outcomes-based assessment and decision making, Oakleaf will develop and deliver a comprehensive review of the quantitative and qualitative literature, methodologies, and best practices currently in place for demonstrating the value of academic libraries.

"ACRL is very pleased to work with Megan Oakleaf on this project," said ACRL President Lori A. Goetsch of Kansas State University.

"Her experience and expertise in assessment make her the ideal person to review and document existing research and practices to assist the academic library community in articulating our value to the campus community."

The current economic climate and the increased emphasis on assessment and outcomes have compelled academic departments' higher education administrators to make tough decisions regarding the funding of programs and units at their institutions. The primary objective of the comprehensive review is to provide academic librarians with a clearer understanding of what research about the performance of academic libraries already exists, where gaps in this research occur, and to identify the most promising best practices and measures correlated to performance.

Additionally, this review will provide ACRL members with tools and strategies to demonstrate the value of academic libraries to their institutional leadership.
Heinz History Center, is now available as a free online exhibit. Free at Last? writes a new chapter in the early history of race relations in the region by exploring the littleknown fact that slavery persisted in Western Pennsylvania through the years immediately preceding the Civil War. The exhibit centers on 55 handwritten records of legal transactions in Pittsburgh between 1792 and 1857 that were discovered in 2007 by staff of the Allegheny County Recorder of Deeds Office. Those faded records, now property of the Heinz History Center, document the area's decades-long involvement with Black slavery and indentured servitude.

Developed by UP's University Library System (ULS), the Web exhibit includes five sections that organize the story-Middle Passage to Early America, the Freedom Papers, Fugitive Slave Laws and Escapes, Abolition, and Civil War and Aftermath; video segments narrated by Laurence Glasco, UP professor of history and the exhibition's historical director, which explain the significance of the documents and tales of some fugitive slaves' escapes to freedom; a zoom and navigation tool to closely inspect the original documents; transcript of handwritten texts; and a photo gallery of 81 thumbnail images with a slideshow or the option to click for a full photo and explanation. The exhibit. which won six 2009 Golden Triangle Awards from the International Association of Business Communicators, is available online at www. library.pitt.edu/freeatlast/.

\section{First New England member joins LYRASIS Mass Digitization Collaborative}

The College of the Atlantic, located in Bar Harbor, Maine, is the first LYRASIS member from its New England region to join the LYRASIS Mass Digitization Collaborative (MDC). The collaborative now has active participants from the Mid-Atlantic, Southeastern, and New England regions. The collaborative was established to assist members with their digitization needs. As part of this effort, LYRASIS has joined the Open Content Alliance, which supports free and open access to the rich cultural heritage materials of LYRASIS member institutions. LYRASIS partners with the Internet Archive to share the new digital resources on the Web.

The collaborative is funded by the LYRASIS membership and supported in part through a grant from the Alfred P. Sloan Foundation. Currently, 39 libraries and cultural heritage institutions are members of MDC, 
including the newest participants: American University, Emory University, Mary Baldwin College, North Georgia College and State University, Southern Adventist University, and University of South Carolina Upstate.

Additional information on MDC is available on the Lyrasis Web site at www.lyrasis. org/.

\section{Early English Books Online}

ProQuest is extending its Early English Books Online (EEBO) digitization program into continental Europe, beginning with a project featuring holdings from the Danish Royal Library's National Collection. Launched at the end of 2009, the online resource included high-resolution color facsimile images of a wide range of European books produced in the 15 th and 16 th centuries. These will be made freely accessible to members of academic institutions, public libraries, schools and other institutions in Denmark, and available for subscription or purchase outside of Denmark.

EEBO traces the history of printing in Europe from its origins through to the close of the 17th century, offering full-color, high-resolution facsimile images of rare and hard-to-access printed sources. The collec-

\section{Upcoming ACRL e-Learning opportunities}

ACRL is offering a wide variety of online learning opportunities in the coming months to meet the demands of your schedule and budget. Upcoming online seminars include Virtual Reference Competencies: Technical, Communications, and Reference Skills and Knowledge and Instructional Design for Online Teaching and Learning. Text messaging reference, Google Wave, and open source research tools will be featured in upcoming live Webcasts.

Registration for all online seminars and Webcasts qualifies for the ACRL Frequent Learner Program. Register for three ACRL e-Learning events and receive one free registration. Full details and registration information is available on the ACRL Web site at www.ala.org/ala/mgrps/divs/acrl /proftools/elearning.cfm. tion offers access to the early printed books of major libraries, forming a seamless and increasingly comprehensive survey of printing in Europe to 1700. The first collection offers a comprehensive survey of the Royal Library's collection of pre-1601 printed books comprising more than 2,600 items or 500,000 pages, and occupying about 50 meters of linear shelving. It includes Copenhagen's holdings of items listed in Lauritz Nielsen's Dansk Bibliografi 1482-1600 and its supplement (1919-1996). The collection contains all of the Royal Library's Danish and Icelandic imprints produced in the 15th and 16th centuries, from the earliest works printed in Denmark through to works by the astronomer and alchemist Tycho Brahe (1546-1601) issued from his private press at Uranienborg before 1597 , as well as 17 th-century editions of works by Tycho and his follower Johannes Kepler (1571-1630).

Additional information on the project is available at eebo.chadwyck.com/home.

\section{CLIR hidden collections award winners}

The Council on Library and Information Resources (CLIR) recently announced the recipients of the 2009 Cataloging Hidden Special Collections and Archives awards. Created in 2008 with funding from the Andrew W. Mellon Foundation, the awards program supports the identification and cataloging of special collections and archives of high scholarly value that are difficult or impossible to locate. Award recipients create descriptive information for their hidden collections that will eventually be linked to and interoperable with all other projects funded by this grant program.

Winning institutions include College of Charleston Libraries, Marquette University Libraries, Newberry Library, and North Carolina State University Libraries. A detailed list of award winning projects can be found at www.clir.org/hiddencollections/awards /index2009.html.

\section{Columbia commits to open access, joins HathiTrust}

Columbia University has joined several institutions of higher learning in a commitment to a Compact for Open-Access Publishing Equity. Other signatories to the compact are Cornell University, Dartmouth College, 
Harvard University, Massachusetts Institute of Technology, and the University of California-Berkeley. The compact commits signatories to the timely establishment of mechanisms for underwriting reasonable publication fees for open access journal articles authored by researchers without alternative funding. The effort around the compact arose as a result of discussions within the university community about providing sustainable, efficient, and effective business models for journal publishing.

"The growth of this new strategy for support for high quality scholarly communication in the expanding number of open access journals requires our participation and support," said Jim Neal, Columbia's vice president for information services and university librarian.

Additionally, the Columbia has joined HathiTrust, a shared repository for the digitized content from academic and research libraries. The libraries plans to contribute public domain volumes digitized through its partnerships with Google, Microsoft, and the Internet Archive. The Compact for Open-Access Publishing Equity is online at www.oacompact.org/compact/ and information on HathiTrust is available at www. hathitrust.org.

\section{Full-text music journal archives from RIPM}

RIPM Online Archive of Music Periodicals (Full-Text) (ROA), a full-text version of journals indexed in the RIPM Retrospective Index to Music Periodicals, is now available. With new titles added every six months, the first installment of $R O A$ contains 51 rarely available music periodicals selected by specialists. $R O A$ is accessed directly from RIPM's newly designed interface for the RIPM Retrospective Index to Music Periodicals.

$R O A$ provides access to primary source material for the study of music and musical life, including music periodicals dating from the Early Romantic to the Modern periods, from Beethoven to Britten and from Haydn to Hindemith. The database provides page manipulation, including a zoom option, the highlighting of the section of the journal page corresponding to the selected record, and the use of two browser windows to view search results and the corresponding journal page simultaneously. Additional details are available from www.ripm.org.

\section{Mortenson Center launches leadership and training program}

The Mortenson Center for International Library Programs at the University of Illinois at Urbana-Champaign is working with the Bill \& Melinda Gates Foundation to support a training program for public librarians in other countries. Global Libraries, an initiative of the foundation's Global Development Program, is working to transform public libraries into vital resources that can help improve the lives of millions of people. The initiative works with select countries that demonstrate a need and a readiness to help public libraries provide free access to computers and the Internet, and training on how to make full use of these tools.

Two of the foundation's Global Libraries country programs will be selected to participate in the Mortenson Center program, which will expose potential public library leaders and innovators from these countries to different models of successful public libraries. The training consists of a three-week program in the United States, followed by a one-week visit to an additional country.

The Mortenson Center for International Library Program is a professional, nondegree program that seeks to strengthen international ties among libraries and librarians, regardless of geographic location or access to technology. For more information, visit www.library.illinois.edu/mortenson. $\boldsymbol{n}$

\section{Correction}

The membership numbers for AAMES and AFAS in the ACRL Membership Statistics table on page 692 of December 2009 issue were incorrect.AAMES had 369 members in 2009 and 380 in 2008, representing a $2.89 \%$ decline.AFAS had 264 members in 2009 and 260 members in 2008 for a gain of $1.54 \%$. The updated 2008-2009 Annual Report is available on the Web at www.ala. org/ala/mgrps/divs/acrl/about/whatisacrl /annreports/index.cfm . The editors regret the error. 